\title{
用語解説
}

\section{実験考古学（Experimental Archaeology）}

考古学においては, 過去のひとびとが残した様々な人工物が標本として不可欠である。しかし, 考古学者が 眼にする事物 (二標本) は現在のものであり，それらの事物を生み出した過去の行動は観察できない。したがっ て, 行動と結果の対応を自ら学び, 失われた過去の行動を正しく類推 (analogy)することが重要になる. 考古学 における類推は解釈の妥当性を点検するための重要な中位理論であるが, この類推に重要な一翼を担っている のが実験考古学である。実験考古学の理論と方法は, 1980年代の欧米を中心に確立している。ニューアーケオ ロジーの旗手, L.R.Binford教授(ニューメキシコ大学) は, 実験考古学を考古学における中位理論の研究と位置 づけている。使用と痕跡の関係を重視する実験考古学は痕跡学 (traceology) とも関係しているが, 広く実験考 古学からはモノとコトの対応関係にかかわる解釈モデルが得られる.また, 時代と地域を限定しない特長をもっ ていることから，異なる対象に応じた様々な実験考古学がこれまで行われている．無文字社会の狩猟採集民を 研究する先史考古学においては, 石器を使った製作や使用にかかわる実験考古学が代表的である。とりわけ, 石器づくりを扢こなう石器の複製実験は, 先史時代の技術と行動復元にかかわる重要な知見をもたらしている. しかし, 石器の複製は容易ではないといった研究上の難点もある. 石器を必要としない現代人が過去の人々と 同じように石器を複製するには，長期にわたる学習によって複製技術を向上させなければならない。通常，10 年以上の石器製作経験が求められている.

（国士舘大学イラク古代文化研究所・日本学術振興会特別研究員PD 長井 謙治)

\section{ペルソナノシナリオ法}

ペルソナ/シナリオ法は, 作り手の論理ではなく, 利用者の視点に立ったデザインを行うユーザー・センター ド・デザイン ( U C D ) の考え方に基づいた設計開発手法である.

従来の設計プロセスが, 「どのように問題を解決するのか？」といった技術志向でモノを中心に考えを組み立 てていたところを，U C D は,「誰のどんな問題を解決するために作るのか？」「なぜ利用者にとって必要なの か？」といった利用者志向でヒトを中心に考えを組み立てていく.

ペルソナは, フィールドワーク等の調査をもとに作成した利用者モデルで, 利用者が, どんな価值観や目的 を持っているのか, 潜在的にどんな期待を持っているのかといった具体的な人物像を記述する.

またペルソナは, 利用者全員の平均像ではなく, 製品・サービスのターゲットセグメントの中で最も重要で 象徴的な利用者を表している。利用者像を共通言語化することで, 異なった利用者像を描きがちな設計チーム と開発チームが, 特定の利用者に焦点を当てた設計検討を行うことができ, 製品・サービスの魅力や使い勝手 を高める決定を下せるようになる。

このペルソナが, どのような状況で, 商品やサービスをどのように利用し, どのような活動や経験をするの かを，利用者の文脈で描いたストーリーがシナリオとなる.

ペルソナにとって, 商品やサービスを含めた利用経験がどのような価值をもたらすのかを物語風に記述する ことで, デザインコンセプトや必要な機能などの要件を抽出しやすくなる.

実際の利用シーンをわかりやすく伝えることで, 価值を伝えづらい革新的な企画も関係者に伝えやすくする ことができる。シナリオを作成後, 実際の製品・サービスのプロトタイピング, ユーザテストなどを通じて, シナリオの改善を行っていく.

(NEＣＣ＆Ｃイノベーション研究所 主任 植村 弘洋) 